\title{
Osmanlı'dan Cumhuriyete Şehircilik, Mimarî ve Eğitim Anlayışındaki Değişmeler Bağlamında Sivas Kongresi Binasının Tarihçesi
}

\author{
Yrd. Doç. Dr. Kemalettin KUZUCU* \\ ÖZET
}

Ulu önder Mustafa Kemal Atatürk'ün 13 Kasım 1927 tarihinde Sivas'ı gezisi sırasında "Burada bir milletin kurtuluşunu hazırlayan kararlar verildi" cümlesiyle Türk tarihindeki önemini vurguladı̆̆ bina, 1892 ytlında dönemin valisi Mehmed Memduh Paşa tarafından idadi binası olarak yaptırıldı. Ülke çapında açılan idadiler için uygulanan tip proje kapsamında inşa edilen binanın planı Paris'te çizdirilmiş olmakla birlikte, inşası sırasında birtakım yerel mimari unsurlarının uyarlanmasıyla millileştirilmiştir. II. Meşrutiyet'in ilanından sonra okul, sultanîye dönüştürüldü. Binanın tarihteki en önemli işlevi, şüphesiz, 4-12 Eylül 1919 tarihlerinde toplanan Sivas Kongresi'ne ev sahipliği yapmış olmastdır. Ulusal kurtuluş hareketi gayriresmi olarak bu binada örgütlenmiş ve manda yönetiminin kabul edilemeyeceği buradan dünyaya ilan edilmiştir. Bina bir ara yetimhane olarak kullanıldı. Cumhuriyetin ilanından sonra Sivas Lisesi olarak kullanılmaya başladı. Atatürk, ölümüne kadar Sivas'a yaptı̆̆ı gezilerinde binayı mutlaka ziyaret etmiş ve anılarını tazelemiştir. Bina, 1990 yılındaki bir kararla "Sivas Atatürk Kongre ve Etnoğrafya Müzesi” haline getirilerek bugünkü kimliğine kavuşturulmuştur.

Anahtar kelimeler: Osmanlı Devleti, Sivas Kongresi, Atatürk, mimarî, eğitim, idadî, sultanî, modernleşme.

• Kafkas Üniversitesi Fen-Edebiyat Fakültesi Tarih Bölümü Öğretim Üyesi - KARS; kuzucu@yahoo.com; Belgegeçer: 04742121 185; Telefon: 04742124386-05357855610. 


\section{From Ottoman to the Republic History of Sivas Congress House in the Context of Changes in Architectural and Educational Understanding \\ ABSTRACT}

House which was described by M. K. Atatürk with a sentence " here decisions were made which paved a way for nation's independence" and thus giving an emphasis on its importance during his travel to Sivas, was constructed by Sivas governor Memduh Pasha as a "idadî" (high school). It was constructed in the context of a type-project applied to other high schools throughout country and its plan originally was drawn in Paris. At the same time, by adding some local elements its was nationalised. After the Second Meşrutiyet was established the school was modified to another type of school called Sultani. The house's most important function in history was that it was used as Sivas Congress House. National struggle was organised informally in this house and it was announced to the world that any other country's sovereignity would not be accepted in any way. For some time it was utilised as orphanage and after the establishment of the Republic it was used as Sivas High School. By the time he passed away in his travel to Sivas Atatürk visited the house without fail and refreshed his memories. With a decision taken in 1990, the house was modified and took its new identity as "Sivas Atatürk Congress House and Ethnograffic Museum".

Key Words: Ottoman Empire, Sivas Congress, Atatürk, architecture, education, idadî, sultanî (high school), modernisation.

Günümüzde Sivas Atatürk Kongre ve Etnoğrafya Müzesi olarak kullanılan ve yaygın adıyla Kongre Binası olarak bilinen yapı, Osmanlı döneminden günümüze intikal eden en değerli kültürel varlıklarımızdan ve abidevi eserlerimizden birisidir. Bu yazıda, modernleşme bağlamında dönemin eğitim, kültür ve mimari anlayışına göz atılacak; tarihimizin son bir buçuk asırlık kesitinin siyasi, sosyal ve kültürel ortamı içerisinde, binanın inşa edildiği tarihten günümüze kadar yüklenmiş olduğu işlevler üzerinde durulacaktır.

Yapı, XIX. yüzyılın ikinci yarısının eğitim politikasına uygun biçimde idadî binası olarak inşa edildiği için öncelikle idadî okullarının kuruluş felsefesine ve bunlar için yaptırılan binalarda uygulanan mimari anlayışa işaret etmek gerekir. "Hazırlamak", "geliştirmek" anlamındaki Arapça 'idad kökünden türeyen idâdî kelimesi, "hazırlama yeri" anlamıyla mekan ismini ifade etmektedir. Terim olarak ise, "kendisinden üstün bulunan herhangi bir mektebe talebe hazırlayan ve yetiştiren okul" manasında kullanılmıştır. Bu anlamda idadî kelimesi 1838 yılından itibaren eğitim literatürüne girmiş ve 
birçok okulun hazırlık sınıfına idadî denmiştir.' Kelimenin bu amaçla kullanılması 1869 yılına kadar devam etmiş ve bu süre zarfında idadî kavramı hiçbir zaman bağımsız bir okulu nitelememiştir. İdâdî terimi, Osmanlı'da modern eğitimin ilk basamağını teşkil eden 1869 tarihli maarif nizamnamesinde gerçek anlamını kazanmış ve başlı başına orta öğretimin bir kademesi olarak ele alınmıştır. Bununla rüşdiyelerden bir derece yüksek ve bugünkü lise düzeyindeki okullar kastedilmiştir. Nizamnamede idadî okulları, rüşdiye mezunu Müslüman ve gayrimüslim çocuklarının bir arada öğretim yaptıkları yer olarak tanımlanmıştır. ${ }^{2}$ Gerçekten de hükümet idâdî programıyla hem yüksek okullara öğrenci, hem de devletin üst kademelerine memur yetiştirmeyi hedeflemişti. İki toplum çocuklarının bir çatı altında eğitilmeleri ise, Tanzimat devri eğitim sisteminin temel unsuru olan Osmanlıcılık ilkesinin hayata geçirilmesi için gerekli görülmüștü. Bu sayede farklı din ve milliyete sahip gençler birbirleriyle kaynaşacak, aynı duyguları paylaşan vatandaşlar olarak "Osmanlı milleti"nin temelini oluşturacaklardı. ${ }^{3}$

İdadî okullarının faaliyete geçmesi 1873 yılını buldu. Yeni Maarif Nazırı Ahmed Cevdet Paşa hükümete sunduğu bir raporda, memleketin ilerlemesi için idadî okullarının kurulmasının zorunluluğuna dikkat çekerek, vilayetler için model oluşturacak bir sivil idadînin İstanbul'da açılmasını önerdi. ${ }^{4}$ Dârülmaârif' in idadîye dönüştürülmesiyle ilk sivil idadî okulu açıldı. Bundan iki yıl sonra Mora Yenişehir'inde açılan idadî ise, vilayetlerdeki idadîlerin ilkini teşkil etti. II. Abdülhamid'in tahta çıktığı 1876 yılına kadar İstanbul'da dört veya beş, taşrada ise sadece bir idadî bulunmaktaydı. İdadî politikasının ağır işlemesi, yeni padişahın eğitim programında öncelikli meselelerden biri olarak ele alınmış ve bu kurumun geliştirilmesi hedeflenmiştir. ${ }^{5}$ Bununla birlikte, ekonomik kriz ve devletin sürüklendiği borç batağı yüzünden II. Abdülhamid'in ilk on yılında da ilerleme sağlanamadı. O sırada sadrazam Said Pașa'nın, öșür vergisinin bir kısmının maarif davasına tahsis edilmesini teklif etmesiyle kaynak sorununun çözülmesi üzerine, 1885 yılında vilayet idadîleri daha ciddi biçimde ele alındı. Bu yılın sonlarında Bursa, Yanya, Edirne ve Kale-i Sultâniye idadîleri faaliyete geçti. Bunları, aralarında Sivas'ın da bulunduğu

' Osman Ergin, Türk Maarif Tarihi, Eser Matbaası, İstanbul 1977, II, 497. Bununla birlikte, bazı yazarlar, 19. yüzyılın ortalarında askerî okullara öğrenci yetiştirmek üzere açılan kurumları idadî olarak nitelemiştir. Örneğin 1845 yılında, askerî okullara alınacak öğrencilerin daha önce bir hazırlık okulundan geçirilmesi amacıyla on iki yerde Mekteb-i Fünûn-1 İdâdiyye adıyla okullar açılması kararlaştırılmıştı. Ancak türlü imkânsızlıklar nedeniyle bu okullar II. Abdülhamid dönemine kadar, amacına ulaşamamıştır (Cemil Öztürk, "İdâdî", DiA , İstanbul 2000, XXI, 465).

2 "Otuz Ü̧üncü Madde: Mekâtib-i idâdiyye mekâtib-i rüşdiyyede ikmâl-i tahsil etmiş olan İslâm ile sunûf-l gayr-i müslime çocuklarının muhtelitan ta'lim ve tedrisleri için mevzu'dur" (Mahmud Cevad, Maarif-i Umûmiye Nezâreti Tarihçe-i Teşkilat ve İcraatı, İstanbul 1338, I, 477).

${ }^{3}$ Bayram Kodaman, Abdülhamid Devri Eğitim Sistemi, TTK, Ankara 1991, s. 114-115; C. Öztürk, İdadi, a.y.

${ }^{4}$ Benjamin J. Fortna, Mekteb-i Hümayûn Osmanl Imparatorluğu'nun Son Döneminde İlam, Devlet ve Eğitim, çev. P. Siral, İletişim Yayınları, İstanbul 2005, s. 150.

${ }^{5}$ B. Kodaman, Abdülhamid Devri Eğitim Sistemi, s. 119. 
24 birimde açılan idadîler izledi. Said Paşa, hatıralarında, Maarif Nezareti yetkililerinin görevlerine henüz alışamadıklarını, bu nedenle sadaret makamının etkinliğini kullanarak, idadîlerin açılmasında olduğu kadar inşaatlarının yapılmasında da kendisinin büyük emeği bulunduğunu belirtir. Yerel yöneticilerle yaptığı yazışmalarda, okul binalarının derhal faaliyete geçirilmesi için aceleci davrandığını anlatır. ${ }^{6}$

Bu dönemde, bazı devlet adamlarının hükümete sunduğu layihalarda, idadî programını eleştiren görüşler ileri sürülmüştür. Bunlar, idadîleri yaygınlaştırmak yerine, ibtidâîleri geliştirmenin daha yararlı olacağını savunuyorlardı. Bu görüşlerin aksine hükümet 1887 'den itibaren idadîlerin sayısını arttırmış ve bunların binalarının yapımına hız vermiştir. ${ }^{7} 1891$ yılı sonu itibarıyla 40 idadînin inşası tamamlanmıştı. İnşaatı devam edenlerle birlikte toplam idadî sayısı 107'ye ulaşmaktaydı. Bir yıl sonra Maarif Nazırı Ahmed Zühdü başkanlığında toplanan maarif komisyonu, taşra idadîlerinin durumunu görüştü ve bu okulların ıslahına yönelik birtakım önlemler saptandı. Bunlardan en önemlisi, eğitime en fazla ihtiyaç duyan köylü çocuklarının da faydalanabilmesi amacıyla, taşra idadîlerinin yatılı programlarının açılması ve bundan sonra inşa edilecek idadîlerin de ikili programa göre inşa edilmeleriydi. ${ }^{8}$

Maarif Nizamnamesinin 34. maddesi, nüfusu 1.000 hanenin üzerinde olan yerleşim birimlerinde bir idadî inşasını öngörüyordu. ${ }^{9}$ Bu hüküm, Maarif Nezareti'nin okul mimarisi politikasını yansıtmaktayd. Nizamnamede yer alan "tesis olunacak mekâtib-i rüşdiye ebniyesi meclis- $i$ kebir-i maâriften verilecek resme tatbikan inşa kılınacaktır" maddesi idadîler için uygulanmaya konuldu. Yani idadîlerin planı maarif meclisi nezaretinde, uzman mühendislerce çizilecekti. İdadîler için, devletin merkezî örgütlenmesini ve Tanzimat sonrası Batı'ya dönük eğitim anlayışını simgeleyen bir mimarî üslup seçilmesi gerekiyordu. ${ }^{10} \mathrm{Bu}$ konuda en doyurucu bilgiyi yine Said Paşa'nın hatıralarında buluyoruz. Said Paşa, o tarihte Batı'da yaygın beş mimari üsluba karșılık Osmanlı'nın da milli bir mimari tarzı bulunduğunu belirtir, bununla birlikte mevcut mimarların kişisel çıkar ve kazançlarını ön planda tutmalarından dolayı memlekette idealist mimar bulunmadığından yakınır. Said Paşa, millı̂ mimariyi geliştirmek istemelerine rağmen, bu sahada yeterince uzman bulunmadığını,

${ }^{6}$ Said Paşa'nın Hâturâtı, Dersaadet 1328, I, 156.

${ }^{7}$ B. Kodaman, Abdülhamid Devri Ĕgitim Sistemi, s. 121. Yüksekokul sayısı arttırmak yerine, ilköğretim programının canlandırılmasını savunanlardan birisi de Sivas Maarif müdürü Ahmed Hulusi'dir. Eğitim reformuyla ilgili olarak Anadolu müfettiși Ahmed Sakir Paşa'ya görüşler sunan Ahmed Hulusi, toplumda her bireyin alim olması gerekmediğini, fakat herkesin en azından okuma-yazma öğrenmesinin daha elzem olduğunu ileri sürmüştü. Ona göre Prusya'nın kalkınmasının en önemli nedeni de okuma-yazma oranının fazlalığıydı (22 Haziran 1896/11 M 1314, Başbakanlık Osmanlı Arşivi (BOA), Yıldız Esas Evrakı (Y.EE), nr. 131/26).

${ }^{8} 4$ Ocak 1892 (4 C 1309), BOA, Sûrâ-yı Devlet (SD), nr. 211/47.

9 "Bin haneyi mütecâviz olan ve hal ve mevkilerince lüzum görünen kasabalarda birer mekteb-i idâdiye yapılmak mukarrerdir" (Mahmud Cevad, Maarif-i Umûmiye Nezâreti, 477).

${ }^{10}$ Burcu Özgüven, "İdadî Binaları", Tarih ve Toplum, S. 82, Ekim 1990, s. 44. 
üstelik bunun ağır mali yük gerektirdiğini savunmuştur. Öte yandan klasik bina içi düzenlemelerini, çağdaş ve modern okullara uyarlamanın güçlüklerinden dolayı, idadî binalarının planlarını Avrupa'dan getirtmek zorunda kaldıklarını belirtmiştir. Nitekim Said Paşa, Paris sefiri Esad Paşa'dan, çeşitli okul plan ve krokileri ister. Bunlar gelince çoğaltılarak birer örneği vilayetlerdeki yetkili mercilere gönderilir ve inşa sırasında bu planlara uyulması istenir. ${ }^{11}$ Mahmud Cevad, vilayetlere gönderilen planların sayısının seksen olduğunu ve sancak merkezleriyle, görece büyük kaza ve kasabalarda inşa edilecek idadîlerin 200 ve 300 öğrenci barındırabilecek ölçekte olduğunu belirtmiştir. ${ }^{12}$

Sivas'ta idadî açılması yolundaki ilk girişim Zeynelâbidin Paşa'nın valiliği zamanındadır. 1879 yılında sadece altı ay görev yapan Âbidin Paşa, Sivas'ta on ibtidâi ile bir idadî inşası ve buralarda görev yapacak öğretmenlerinin maaşının karşılanması amacıyla bir yardım kampanyası başlatmıştı. Kendisinin de yüklü miktarda bağıșta bulunduğu kampanyada bir hafta içerisinde 50 bin kuruş topland. ${ }^{13}$ Ancak projenin gerçekleştirilebilmesi için 60-70 bin kuruş daha gerekliydi. Zeynelâbidin Paşa Dâhiliye Nezareti'ne telgraf göndererek, belirtilen paranın -sonradan vakıflar gelirlerinden karşılanmak üzere- belediye meclisi bütçesinden aktarılmasını önerdi. Şûrâ-yı Devlet'te yapılan görüşmelerde valinin teklifi uygun bulundu. ${ }^{14}$ Fakat bu sırada Âbidin Paşa'nın Selanik valiliğine atanması üzerine okullarla ilgili proje gerçekleştirilemedi. Ardılı İsmail Hakkı Paşa'nın valiliği zamanında (1880-1882) eğitim alanında önemli ilerleme sağlanmış, Sivas'ta dört ibtidâi ile iki rüşdiye inşa edilmiştir. Hakkı Paşa'nın asıl hedefi, Sivas sancağında bir idadî açmaktı. Fakat bunun halktan toplanacak paralarla yapılmasının imkânsız olduğunu düşünüyordu. Vali Paşa, bu konuda, vilayetten tahsil edilen öşürün idadî inşası işine sarf edilmesini ve 1882 yllında inşaata başlanmasını önerdi. ${ }^{15}$ Bununla birlikte idadî planı İsmail Hakkı Paşa döneminde de hayata geçirilemedi. Sivas'ta bayındırlık alanında birçok yenilik gerçekleștirmesinin yanında, vilayeti çok sayıda modern okulla donatan Halil Rifat Paşa (1882-1885) da idadîyi açmaya muvaffak olamamış, ${ }^{16}$ Sivas idadîsi ancak Sırrı Paşa'nın valiliğinin ikinci yılında, 1887 'de açılabilmistir. Okulun kendi binasının yapılması beklenmeden eğitime başlanması $1{ }^{17}$ yöneticilerin bu işteki kararlığını ve aceleciliğini yansıtan bir tutum olarak dikkat çekmektedir.

"Said Paşa'nın Hatırâtı, s. 157.

${ }^{12}$ Mahmud Cevad, Maarif-i Umûmiye Nezâreti, s. 246.

${ }_{13}^{13}$ Sivas, nr. 1, 30 Muharrem 1297.

${ }_{14} 26$ Subat 1880 (15 RA 1297), BOA, SD, nr. 1783/54

is 14 Ekim 1880 (9 ZA 1297), BOA, Yıldız Perakende Evrakı Umum Vilayetler Maruzatı (Y.PRK.UM), nr. 3/51.

${ }^{16}$ Halil Rıfat Paşa zamanında Sivas'ta, içerisinde 4 derslik, 1 resimhane, 1 salon ve 3 oda bulunan bir mülkiye rüşdiyesi; 4 derslik, 1 resimhane, 1 salon ve 5 odası bulunan askerî rüşdiye ile bir öğretmen evi ve eğitim-öğretim işlerini yürüten maarif dairesi inşa edilmiştir (Salnâme-i Vilayet-i Sivas, nr. 15, Sivas 1308, s. 74).

${ }^{17}$ Taşra idadîlerinin kendi binaları inşa edilinceye kadar, önceden var olan yapıların okul haline getirilmesine örnek olması bakımından, Konya şehrinde yeni yapılmış olan 
Bu dönemde Sivas vilayet merkezinde orta öğretim okulu olarak askerî ve mülkî rüşdiye okulları ile iki sınıflı bir muallim mektebi bulunuyordu ve bu üç okul, üç katlı bir binada eğitim vermekte idi. Bina her ne kadar büyük olsa da, üç okulu barındırmaya yeterli değildi. Yeni kurulan idadînin eğitim faaliyetini bu binada yürütemeyeceği, bunun yanında bir süre sonra kız rüşdiyesinin de açılacağı dikkate alınarak, yeni bir okul binası inşa edilmesi kararlaştırıldı ${ }^{18}$ İdadî öğrencileri ise, henüz ilga edilmiş olan mülkî rüşdiye binasına yerleştirildi. ${ }^{19}$ Vali Mehmed Memduh Paşa, askerî depo karşısındaki vakıf arsasının bu iş için uygun olacağını düşündü. Gerekli plan ve projeyi hazırlatıp, 481.392 kurus 26 para olarak belirlenen keşif bedeliyle Dâhiliye Nezareti'ne başvurdu. İdadi binası 300 öğrenci barındıracak büyüklükte tasarlanmıştı. Maarif Nazırı Münif Paşa, valinin keşif defteriyle inşaat planını inceleyip onayladıktan sonra Şûrâ-yı Devlet'e gönderdi. ${ }^{20}$ Meclisteki görüşmelerde, yapılması tasarlanan binanın büyüklüguünden dolayı götürü usulüyle inșasına kimsenin yanașmayacağı hesaba katılarak, bunun devlet eliyle yapılması uygun görüldü. Meclisin bu kararı almasında, muhtemel yolsuzlukların önüne geçmek ve inşaat kurallarına uygun biçimde olabildiğince dayanıklı bir yapı vücuda getirebilmek düşüncesi etkili olmuştu. İnşaat faaliyetlerini yürütmek üzere vilayet idare meclisi ve belediye azasından birer kişi ile, belediye mühendisinden oluşan bir komisyon kuruldu. ${ }^{21}$ Nihayet II. Abdülhamid'in iradesiyle "masârifinin emsâli veçhile mahalline ait maârif hissesinden tesviye edilmek üzere" Sivas idadîsinin inşasına başland ${ }^{22}$. Binanın temeli 1890 sonbaharında atıldı ${ }^{23}$.

Binanın yapılacağı arsa, Romalılardan beri pek çok tarihi vakalara sahne olmuş ve birkaç sene öncesine gelinceye kadar yer yer kalıntılarına rastlanan kalenin teşkil ettiği duvar açılarından birinin içinde mahsur kalmış, kısmen bataklıktan ibaret bir arazi idi. ${ }^{24}$ Böyle bir arsanın benimsenmesi, Tanzimat bürokratı ve valilerinin şehircilik felsefesiyle açıklanabilir. Tanzimat valileri, hükümet, kışla ve askeri depo gibi büyük binaları şehir

hastane binasının, muvakkaten mekteb-i idadîye çevrilmesi gösterilebilir (7 Temmuz 1894/4 M 1312, BOA, Bâbıâli Evrak Odası, Sadaret Mektubî Mühimme Kısmı (BEO., A.MKT.MHM), nr. 552/22). Aynı şekilde Bağdat idâdisi, daha önce fakirler için açılan bir hastanede faaliyete geçerken, Şam'da ise özel okul olarak kullanılan yapı, idâdiye dönüştürülmüştür (B. J. Fortna, Mekteb-i Hümayûn, s. 178). s. 516.

${ }^{18}$ Hasan-Âli Yücel, Türkiye'de Orta Ögrretim, Kültür Bakanlığı Yayınları, Ankara 1994,

ig İnşaatın tamamlanmasından sonraki tarihe ait bu belgede geçen "mülgâ rüşdiye- $i$ mülkiye dâiresinde bulunan Mekteb-i idâdî memurîn ve talebesi binâ-yl cedîde nakledildiği..." ibaresi, idâdî öğrencilerinin geçici olarak yerleştirildikleri bina hakkında fikir vermektedir (16 Ocak 1894/9 B 1311, BOA, Yıldız Evrakı Mütenevvia Kısmı (Y.MTV), nr. 89/35).

${ }^{20}$ Maarif Nezareti'nden Şûrâ-yı Devlete Gönderilen Tezkere, 25 Şubat 1890 (5 B 1307), BOA, Irade Meclis-i Mahsus, nr. 4781, lef 1.

${ }^{21} 9$ Nisan 1890 (19 S 1307), BOA, Meclis-i Vükelâ Mazbataları (MV), nr. 53/22.

${ }^{22} 3$ Mayıs 1890 (14 N 1307), BOA, İrade Meclis-i Mahsus, nr. 4781, lef 3.

${ }^{23}$ Memduh Paşa zamanında Amasya sancağına idadî yapılması için irade çıkmıştır (Salnâme-i Vilayet-i Sivas, nr. 15, Sivas 1308, s. 88-89). s. 516 .

${ }^{24}$ Hasan-Âli Yücel, Türkiye'de Orta Öğretim, Kültür Bakanlığı Yayınları, Ankara 1994, 
dışına yapmak istemiştir. Çünkü eski medeniyetlerden kalma surlar şehirlerin fizikî gelişmesine engel olmakta idi. Bu anlayışlarla vücuda getirilen resmî binaların gerek cephe, gerekse plan ve kitle kuruluşlarında belirli bir "devlet mimarisi" nin egemen kılındığı ve bu tarzın vilayetlerdeki resmî yapılarda standart biçimler yoluyla yaygınlaştırıldı ğı görülmektedir. ${ }^{25}$ Sivas idadîsinin bu arazide inşa edilmesinde, bir yandan söz konusu bataklığın kurutularak bir nevi çevre düzenlemesi yapılması, diğer yandan da, sur içinde sıkışmış olan şehir yerleşiminin genişletilmek istenmesi gibi iki temel düşüncenin hâkim olduğu söylenebilir.

Said Paşa'nın "vücûda gelen mekâtib-i idâdiyyenin eşkâl ve taksimâtı Paris mekteplerininkine mutâbıktır" cümlesi, idadîlerin planı hakkında fikir vermektedir. Bunun yanında, nezaretçe belirlenen birtakım yerel unsurların uyarlanması suretiyle idadî binaları millîleştirilmiştir. Maarif Nezareti'nde gözden geçirilen planlar, bugün "tip proje olarak adlandırılan yöntemle, inşa edilecek yerin nüfusu, ögrenci adedi tahmin edilerek, belirli bir kapasite hedeflenerek her yöreye ve araziye uygulanabilecek biçimde hazırlanmıştır. Planlar bina büyüklüğü ve programına göre belirli tiplere ayrılıyor, ancak cepheler ve plan kurguları açısından benzer özellikler gösteriyordu. İdadîler genel olarak üç plan tipinde inşa edilmiştir. Birinci tip plan İstanbul ve Balkan şehirlerinde, ikinci tip İzmit, Samsun ve Balıkesir gibi nüfusça orta büyüklükteki yerleşmelerde, üçüncü tip ise büyük merkezlerde uygulanmıştır. Sivas, İzmir, Manisa ve Bursa idadîleri üçüncü plan tipine girmektedir. Kareye yakın bir biçim olan bu plana göre, giriş kapısının iki yanında sınıflar ve odalar konumlanmış; binanın iç kısmındaki mekânların karanlıklaşmasını önlemek ve yapımda gereksiz harcamadan kaçınmak için orta yere avlu tasarlanmıştır. Hem yatılı, hem de gündüzlü öğrenciler için yapılan yedi derslikli binalarda laboratuar, yemekhane, kiler, hamam ve yatakhane bölümleri bulunmaktayd ${ }_{1}{ }^{26}$ Bursa idadîsinin inşasına izin veren belgede, depreme dayanıklı olarak yapılmasına özen gösterilmesinin istenmiş olması ${ }^{27}$ idadî binaların yapımı sırasında yörelerin tektonik özelliklerinin göz önünde bulundurulduğunu göstermektedir.

Sivas idadîsinin inşaatı 3 Ekim 1892 tarihinde tamamlandı. Bunu, hattat Sivaslı Mahmud Edib tarafından mermer üzerine ta'lik stilinde yazılmış kitabedeki 12 Rebîulevvel 1310 tarihinden anlıyoruz. ${ }^{28}$ Inşa masrafı keşif

${ }^{25}$ Tanzimat valilerinin șehir planlamasındaki esin kaynakları, Viyana gibi Avrupa başkentlerindeki uygulamalardır. Yeni anlayışın tipik örnekleri Diyarbakır, Elazığ ve Ankara'da görülmektedir. Buralarda geleneksel doku korunmuş olmakla birlikte, yeni yapılan resmî binaların surların dısında insa edilmesiyle sehrin daha genis alanlara kaydırılması sağlanmıştır ("Söyleşi: Osmanlı'dan Bugüne Hükümet Konakları", Yöneten: G. Birkan, Katılanlar: I. Ortaylı ve dğr., Mimarlık, S. 84/5, Mayıs 1984, s. 203; B. Özgüven, İdadi Binaları, s. 45).

${ }^{26}$ B. Özgüven, İdadi Binaları, s. 45-46.

${ }^{27} 25$ Temmuz 1887 (4 ZA 1304), BOA, BEO., A.MKT.MHM, nr. 494/24.

${ }^{28}$ Kitabe metni șudur: "Sevketlü Gazi Abdülhamid Han-ı Sân̂ hazretlerinin zaman-ı saltanatlarında rütbe-i bâlâ ricâlinden Mazlum Paşa-zâde Mehmed Memduh Beyefendi'nin Sivas vilayeti valiliğinde işbu mekteb-i idadî-i mülkî inşa olundu. 12 Rebîulevvel sene 1310. 
defterinde belirtilen rakamın yaklaşık iki katı olarak gerçekleşmiş ve bina 814.000 kuruşa mal olmuştu. ${ }^{29}$ Okul yeni binasına 1893 yılında taşındı. Bundan boşalan bina ise önce askerî rüşdiye mektebine devredildi, ${ }^{30}$ daha sonra kız okuluna verildi. ${ }^{31}$ Bina hizmete girdikten sonra yatılı kısmına talep artınca, yatılı okul ihtiyaçlarını karşılamak amacıyla binanın arka kısmında mutfak, hamam ve kiler yapıldı ${ }^{32}$ Osmanlı Arşivi belgelerinde binayı inşa eden ustalarla ilgili bilgilere rastlanmamaktadır; bununla birlikte, diğer vilayetlerdeki örnekleri gibi Sivas idadîsi de, yerel Ermeni ve Müslüman ustalarca yapılmış olmalıdır. Belgeler daha çok mali konularda merkezi hükümet ile Sivas arasında vuku bulan yazışmalara aittir. Şûrâ-yı Devlet tasnifinde bulunan bir hülasada, idadî ile ilgili yazışma evraklarının yanı sıra binanın planı ve keşif defterinin de bulunduğu belirtilmiştir. ${ }^{33}$ Ancak dosya halindeki bu belgeler henüz araştırmaya açılmadığından, inceleme ve yayımlama imkânından şimdilik mahrumuz.

Sivas idadîsinin inşasında vali Memduh Paşa'nın şahsi gayretlerinin önemli payı bulunmaktadır. Memduh Paşa döneminde Sivas, Vilayât-1 Sitte'nin önemli merkezlerinden biri olarak, Ermeni komitacılarının çıkardığı kargaşanın tesiri altında bulunuyordu. Vilayette faaliyet gösteren misyoner okullarında Ermeni gençleri Türk yetkililerin denetiminden uzakta eğitim görmekte, ayrılıkçı eğilimlere yönelmekte idiler. Kimi zaman Müslüman öğrenciler de bu okullara devam etmek zorunda kalmaktaydı. Ermeni sorununun askerî yöntemlerle çözülemeyeceğini ileri süren Memduh Paşa, bu tür yaklaşımların ahali üzerinde psikolojik baskı oluşturduğunu düşünmekteydi. $O$, bayındırlık, eğitim ve kültür sahalarında atılacak adımlarla meselenin kendiliğinden ortadan kalkacağını savunuyordu. Misyoner okullarına devam eden gayrimüslim öğrencilerin idadîlere çekilmesi halinde, hem bunların devlete bağlılıklarının sağlanacağını, hem de kontrol altında tutulacaklarını düşünüyordu. ${ }^{34}$ Ülkenin kurtuluşunu eğitim seferberliğinde gören Memduh Paşa, hurafelere ve batıl düşüncelere sahip insanların aydınlatılmasını savunuyor; bunun için de gerek Anadolu'da gerekse Rumeli'de yeni ve modern okullar açılarak bütün halkın mutlaka eğitilmesini ve iki toplum arasındaki kültürel bağların güçlendirilmesini istiyordu. Memduh Paşa Sivas'ta etnik ve mezhepsel farklılıkları hükümet

Mahmud Edib-i Sivasî." (Hikmet Denizli, Sivas Tarihi ve Anıtları, Özbelsan A. Ş. Yayını, Sivas Ts, s. 165).

${ }^{2 y}$ Salnâme-i Nezâret-i Maârif-i Umûmiyye, Dördüncü Sene, İstanbul 1319, s. 692.

${ }^{30} 24$ Kasım 1893 (15 CA 1311), BOA, Irade Hususiye, nr. 42/CA 1311.

${ }^{31}$ BOA, Y.MTV., nr. 89/35. Hükümetin hiçbir parasal katkısı olmaksızın tamamen ahalinin yardımıyla yapılmıs olan rüşdiye binası, 1894 yılında meydana gelen bir depremde zarar görecek okulun boşaltılarak sanayi mektebine taşınması istenecektir (21 Kasım 1893/12 CA 1311, BOA, Y.MTV., nr. 87/71; 17 Ekim 1894/17 Rebîulâhir 1312, BOA, ŞD, nr. 1798/3).

${ }^{32} \mathrm{H}$. Â. Yücel, Türkiye'de Orta Öğretim, a.y.

${ }^{33}$ Numarası bulunmayan 6 Receb 1307 tarihli belgenin hülasası için bk. BOA, Şûrâ-yı Devlet Katalogu, Maarif K1sm1, c. I, s. 221.

${ }^{34} 6$ Haziran 1893 (21 RA 1310), BOA, Y. EE., nr. 88/44; 13 Temmuz 1893 (29 Z 1310), BOA, Yıldız Perakende Evrakı Arzuhaller ve Jurnaller (Y.PRK.AZJ), nr. 26/94. 
lehine kullanarak dört ay içinde asayişi sağlamıştır. ${ }^{35}$ Bunun yanında şehir merkezi ile kazalarda yaptırdığı çeşme, köprü, kaldırım, yol, telgraf hatları ve okulların yanında, bayındırlık, eğitim ve kültür alanında büyük yenilikler getirmiştir. ${ }^{36}$ İdadî binası, onun bu hizmetlerini taçlandırır niteliktedir. Bu yüzden olsa gerek bazı yazarlar, idadî okulunun, selefi zamanında yapılan hükümet binasının karşısında inşa edildiğine dikkat çekerek, Halil Rıfat Paşa'nın vilayette yaptığı işlerle kazandığı haklı şöhret ve hürmetin yanında sönük kalmaması için Memduh Paşa'nın okul binasına büyük titizlik gösterdiğini ileri sürmektedirler. ${ }^{37}$

Sivas idadîsinin mimarî görünümü, aynı dönemde inşa edilen diğer idadîler gibi, Fransız benzerleri örnek alınarak yapıldığı düşüncesini doğrular niteliktedir. İdadîlerin çoğu, tıpkı Fransa'daki çağdaş binalarda olduğu gibi, hem plan hem de yükseklik açısından aşırı simetrik ve tasarım olarak da neoklasiktir ${ }^{38}$ Ağırlıklı malzemesini taşın oluşturduğu Sivas idadîsi doğu yönünden üç, batı yönünden iki katlıdır. Dikdörtgen planlı dış ölçüleri 33,5X39,5 metredir. Beden duvarları kesme taş ve moloz taş örgülü, mekânları ayıran duvarları ise ahşap arası taş dolgu bağdadî tarzdadır. İç ara bölmelerin ve mekânların tavan ve tabanı ahşap, üst örtüsü kiremitle kaplı çatı şeklindedir. Ortada 7X14 metre iç ölçülerinde, yüksekliği 16 metre olan dikdörtgen planlı bir iç avlusu vardır. Önceleri şadırvanlı olan orta avlunun üzeri camla kapatılmıştır. Dört ana yönde kapısı olup kuzey ve güneydekilerden bodrum kata girilmekte, doğu ve batıdaki kapılar zemin kata açılmaktadır. Bodrumdan zemin kata çıkış merdivenle sağlanmaktadır. Zemin katta 15 oda bulunmaktadır. Sonradan yapılan tamirler sırasında zemin katın tabanı ile üst kata çıkan merdiven betonarme tekniğinde yenilenmiştir. Güney ve kuzey yönündeki merdivenlerin ahşap korkulukları orijinalitesini muhafaza etmektedir. Üst katın taban ve tavanı ahşaptır. Oda ve salonlar koridorun çevresinde sıralanmış ve derslikler cephelere yansımıştır. Merdiven çıkışlarındaki tavanlar çift daire biçimli, ahşap çarkıfelek motifli ve ahşap göbeklidir. Yapıldığı tarihlerde tüm oda ve salonların iç duvarlarında süslemelere yer verilmişken, bunlar sonraki onarımlarda kapatılmıştır. Sadece kongre salonu, Atatürk'ün yatak odası ve zemin katta bir odanın duvarları ve tavanı korunmuştur. Kongrenin yapıldığı salon, binanın batı yönünde $6,20 \times 15,5$ metre iç ölçülerinde olup kongre sırasındaki durumu ile korunmaktadır. Zemin kat pencereleri dıştan yuvarlak kemerli, üst kat pencereleri ise üstten kesme taş üçgen alınlıklarla süslenmiştir.

${ }^{35}$ Selim Aslantas, "Bir Osmanlı Bürokratı: Mehmed Memduh Paşa", KÖK Sosyal ve Stratejik Araştırmalar Dergisi, c. III, S. 1 (Bahar 2001), Ankara 2001, s. 1838-200.

${ }^{36} \mathrm{Bu}$ dönemde gerçekleştirilen şehircilik ve bayındırlık hizmetleri hakkında bk. Salnâme-i Vilayet-i Sivas, Defa 15, Sivas 1308, s. 78-94.

${ }^{37}$ H. Â. Yücel, Türkiye'de Orta Öğretim, s. 519; Halûk Çağdaş, "Sivas İdâdîsi", Tarih ve Toplum, S. 90, Haziran 1991, s. 30.

${ }^{38}$ Genellikle büyük ölçekli tutulan idadîlerin hemen hepsi taștan inșa edilmiş kemerli ya da alınlıklı pencereler, süslü merdivenler ve kapılar ile eklemli saçaklar gibi detaylarla bezenmişlerdir (B. J. Fortna, Mekteb-i Hümayûn, s. 175). 
Dış cephelere gelince, asıl girişi batı yönünde olan binanın bu cephesi ile güney ve kuzey cephesinin yarısı tamamen kesme taştan inşa edilmiştir. Diğer cephelerinin köşeleri, silme ve kornişleri kesme taş olup, araları moloz taş örgülü ve üzeri sıvalıdır. ${ }^{39}$ Zemin kat pencereleri dıştan yuvarlak kemerlidir, üst kat pencerelerinin üstünde kesme taş üçgen alınlıklarla cephe hareketlendirilmiştir. Doğu yönündeki girişe çift taraflı kesme taş merdivenlerle çıkılmakta, üst kattaki balkonu silindirik gövdeli dört sütun taşımaktadır ${ }^{40}$ Özgüven'e göre, pencerelerin çevresindeki bantlar, aralardaki ionik plastrlar, kat aralarındaki kornişler, saçak silmeleri ve gizlenen çatılar ile girişteki iki kollu merdivenler neoklasik düzenin hâkim olduğu bir anlayışın görsel elemanlarıdır ${ }^{41}$.

İdadî binalarının iç tasarımları da klasik mektep binalarından ayrılmaktaydı. Bunların sınıflarını medrese dershanelerinden ayıran en önemli fark, toplu eğitim için gerekli sıra, sandalye, karatahta, harita vb. ders araç gerecine uygun boyutlarda geniş pencereli ve havadar derslikler olmasıdır. Bundan dolayıdır ki, birebir ve sözlü eğitime ağırlık veren geleneksel medrese yönteminden toplu halde eğitime ve görselliğin ön planda tutulduğu çağdaş eğitim metodlarına geçiş, Anadolu'nun pek çok şehrinde idadîler yoluyla gerçekleştirilmiştir ${ }^{42}$.

Çağdaş öğretim teknolojilerinden faydalanmayı ilke haline getiren II. Abdülhamid dönemi eğitim politikası, bazı materyallerin zararlı etkilerinden korunmak için, bunların yerli üretimlerinin kullanımını teşvik etmiştir. Bunların başında haritalar gelmektedir. Yurtdışından ithal edilen haritaların siyasi sınırlar konusunda birbirini tutmaması ve bazı Osmanlı topraklarının kasıtlı olarak başka ülkeler sınırları içerisinde gösterilmesi karşısında kimi Osmanlı aydınları haritaların kalleşliğine karşı uyarıcı yazılar yazarken, merkezi hükümet de uyanık ve tedbirli davranmak istemiştir. Zira bu tür haritalardaki yapay sınırlar, genç tebaanın ve proto-yurttaşların siyasi varlığa bağlılığını hedefleyen devlet felsefesine aykırı olduğu kadar, bilhassa Balkan ve Asya topraklarındaki Osmanlı yurttaşlarını kışkırtıcı nitelikteydi ${ }^{43}$. Hükümet 1895 yılında mülkiye mektebi müdürü Abdurrahman Paşa başkanlığında bir komisyon oluşturarak, milli eğitim politikasına uygun haritalar bastırmayı kararlaştırdı. İlk olarak, Paris'te Hachette firması tarafından basılmış olan $100 \mathrm{X} 130 \mathrm{~cm}$. ebadındaki haritaların tercüme ve tashih edilerek basımına girişildi. Avrupa, Asya, Afrika ve Amerika kıtalarıyla genel dünya haritası olmak üzere beş parçadan oluşan haritaların

${ }^{39}$ B. J. Fortna, ülke çapındaki idâdilerin planlarının aynı merkezde hazırlanmasına rağmen, inşaatların bitiminde tek plan tipinden uzak binalar ortaya çıktığını ve bu farklılığın işçilikte de gözlendiğini belirttiği bölümde, Sivas idâdisinin ince sıvalı taş binasıyla, bunun Erzurum'daki kopyasının kaba görünüşü arasındaki zıtlığa dikkat çeker (B. J. Fortna, Mektebi Hümayûn, s. 180).

${ }^{40}$ H. Çağdaş, Sivas İdâdîsi, s. 31; H. Denizli, Sivas Tarihi ve Anttları, s. 166-167.

${ }^{41}$ B. Ỏzgüven, İdadi Binaları, s. 46.

${ }^{42}$ B. Özgüven, İdadi Binaları, s. 45.

${ }^{43}$ B. J. Fortna, Mekteb-i Hümayûn, s. 220-221. 
her birinden 3.000 adet basılacak ve taşra idadîlerine gönderilecekti. ${ }^{44}$ Haritaların basımı üç yılda tamamlandı ve ilgili okullara dağıtıldı. Bu arada geçen süre zarfında okul sayısı arttığ ${ }_{1}$ için, aynı haritaların her birinden ikişer bin adet daha basılması kararlaştırıld $1,{ }^{45}$

Avrupa okullarından esinlenerek inşa edilen idâdi binaları, inşa tarzları, bezemeleri ve İslami kültürün gerektirdiği mekan ve alanlara yer verilmesi bakımından Avrupalı örneklerinden ayrılır. Bunu Sivas idadîsinde açıkça görmek mümkündür. Örneğin padişahın tuğrası, okulun hedeflerini ve kurulușunda padişahın inayetini anlatan kitabesi ve klasik bir görünüm yaratan hilal gibi sembolik öğeler bunlardan birkaçıdır. Bu öğeler, herkesin görebileceği bir noktaya yerleştirilen kaligrafik "Padişahım çok yaşa!" sloganı ile desteklenmiş; böylece, binanın varlık sebebi merkezî hükümete ve onun nihaî otoritesi olan padişaha bağlanmıştır. İçerisinde ise namaz ve merasim alanları oluşturulmak suretiyle Osmanlı ve İslam geleneğinin temel unsurları korunmuş oluyordu. ${ }^{46}$

Sivas idadîsinin faaliyete geçtiği 1892-1893 döneminde 20'si ücretli olmak üzere 33 yatılı öğrencisi bulunuyordu. Aynı yıl yeni kayıt yaptıran 14 öğrenci ile bu sayı 47'ye çıkmıştır. 12 öğrenci çeşitli sebeplerle kaydını sildirirken, 11 öğrenci diploma alarak mezun olmuştur. Böylece bir sonraki yıla 24 öğrenci devredilmiştir. Gündüzlü öğrenci sayısı ise 115 'tir. Okulda idareci, öğretmen ve hademe olarak 29 görevli bulunmaktayd $1 .{ }^{47}$ Bir sonraki 1893-1894 eğitim öğretim yılındaki öğrenci mevcudu 24 yatılı, 49 gündüzlü olmak üzere 73 'e çıkmıştı. ${ }^{48}$ Diğer yıllardaki öğrenci sayılarını Maarif Nezareti salnamelerinden çıkarmak mümkündür. Buna göre 1895 yılında 12 yatılı, 102 gündüzlü talebe öğrenim görmekte iken, ${ }^{49}$ bundan sonraki tarihlerde yatılı öğrenci bulunmadığı anlaşılmaktadır. Öğrenci sayısının 1896 yilında $91,{ }^{50} 1897$ yılında $389,,^{51} 1898$ yilında $296^{52}$ ve 1900 yilında $441^{53}$ olduğu görülmektedir.

${ }^{44} 29$ Mayis 1895 (4 Z 1312), BOA, İrade Maarif, nr. 3/Z 1312.

${ }^{45} 8$ Nisan 1898 (17 ZA 1315), BOA, İrade Maarif, nr. 3/ZA 1315.

${ }^{46}$ B. J. Fortna, Mekteb-i Hümayûn, s. 176.

${ }^{47}$ Maarif-i Umûmiye Nezaret-i Celilesi Idâresinde Bulunan Mekâtib-i İbtidâiyye, Rüssdiye, I'dâdiye, Âliye ile Mekâtib-i Husûsiye ve Ecnebiyyenin ve Dersaâdet'te Tahriri İcrâ Kllınan ve Taşrada Mevcûd Bulunan Kütübhânelerin Itatistiki, 1310-1311 Sene-i Dersiyye-i Mâliyesine Mahsûsdur, Osmaniye Matbaası, Dersaadet, s. 24-25.

${ }_{48}$ Maarif-i Umûmiye Nezaret-i Celilesi İdâresinde Bulunan Mekâtib-i İbtidâiyye, Rüsdiye, I'dâdiye, Âliye ile Mekâtib-i Husûsiye ve Ecnebiyyenin ve Dersaâdet'te Tahriri İcrâ Kılınan ve Taşrada Mevcûd Bulunan Kütübhânelerin Itatistiki, 1311-1312 Sene-i Dersiyye-i Mâliyesine Mahsûsdur, Matbaa-yı Amire, İstanbul 1318, s. 24-25.

${ }^{49}$ Salnâme-i Nezâret-i Maârif-i Umûmiye, Birinci Sene, İstanbul 1316, s. 1093. Bu tarihte Amasya idadîsinin öğrenci sayısı 91 'dir (s. 1094).

${ }^{50}$ Salnâme-i Nezâret-i Maârif-i Umûmiyye, İkinci Sene, İstanbul 1317, s. 1247.

${ }^{51}$ Salnâme-i Nezâret-i Maârif-i Umûmiyye, Üçüncü Sene, İstanbul 1318, s. 1393.

${ }_{52}$ Öğrencilerin 20'si gayrimüslimdir (Salnâme-i Nezâret-i Maârif-i Umûmiyye, Dördüncü Sene, İstanbul 1319, s. 659).

53 Ö́ğrencilerin 421'i Müslüman, 20'si gayrimüslimdir. Bu tarihte Amasya idadîsinin 97, yeni açılan Tokat idadîsinin ise 112 öğrencisi bulunmaktaydı (Salnâme-i Nezâret-i Mâarif-i Umûmiyye, Altıncı Sene, İstanbul 1321, s. 544-545). 
Sivas idadîsinin yönetici kadrosu ve öğretmenleri hakkında nezaret ve valilikçe yayımlanan salnameler doyurucu bilgiler vermektedir. 1896 yılında müdürlük görevini Ziya Bey yürütmekteydi. Muavin-i evvel İhsan Bey, muavin-i sâni Abdurrahman Bey, muavin-i sâlis Panayoti Bey ve muavin-i râbi“ Şükrü Bey'den oluşan dört müdür yardımcısı dışında, birer kâtip (Osman Nuri), hâfız-1 kütüb ve ambar memuru (Tevfik Bey), imam (Abdurrahman Bey) ve tabip (Avakim Bey) ile 7 hademe ve 1 mubassir (belletmen) görev yapmaktaydı. Tek branştaki öğretmenlerin birbirinden farklı dersleri okutmaları, öğretmen açığı bulunduğunu akla getirmektedir. ${ }^{54}$

1896 yılı Haziran ayı itibarıyla yedi yıllık Sivas idadîsinde ulûm-1 diniyye, Arapça, Farsça, Türkçe, Fransızca, hesap, hendese, cebir, müsellesât (trigonometri), kozmografya, makine, coğrafya, tarih, usul-i defterî, malumât-1 fenniye, hikmet-i tabiiyye ve kimya, mevâlid (doğum) ve hıfzıssıhha, kavânin, edebiyat ve ahlak, hüsnühat ve resim dersleri okutulmaktaydı. Haftalık ders saati ise birinci sınıfta 18, ikinci sinıfta 20, diğer sinıflarda ise $25^{\prime}$ ti. $^{55}$

İdadîlerin açılışından itibaren ortaya çıkan muhalefet, bu okulların mezun vermeye başlamasıyla birlikte artarak devam etmiştir. Muhaliflere göre, karyolada yatarak ve alafranga sofralarda ayrı ayrı tabaklarda yemek yiyerek yetişen idadî öğrencileri, mezun olduktan sonra Batı tarzı yaşam kalıplarını tercih etmekte ve kendi örf ve kültürlerini aşağılamakta idiler. Tek emelleri devlet hizmetinde çalışmak olan bu gençler, sanayi ve ziraat işlerinden yüz çeviriyorlardı. Bu ise, Avrupa mallarının ülkeye girişiyle zaten gerilemeye yüz tutan sanayi ve ticaret faaliyetlerini tamamen yok olmakla karşı karşıya getirecekti. Bunun yanında, idadî mezunlarının hepsini istihdam imkânı da yoktu. Yalnızca İstanbul idadîsi bile devletin memur ihtiyacını karşılayabilecek ölçüde mezun vermekteydi. Bu endişelerden dolayı muhalif çevreler, idadîlerde sanayi ve ziraat derslerine ağırlık verilmesini istiyorlardı. Bu görüşler ilgili nezarette olumlu yankı buldu. “...Memleketin kesb-i servet ve ma'muriyet etmesi devlet yüzünden geçinmekle mümkün olmayıp içimizden tüccar ve ehli sanat yetiştirmeye mütevakkıf olduğu" ifade edilerek; bu okulların ders programlarında değişikliğe gidilebileceği belirtildi. Padişahın da onayıyla programa ilm-i servet ve fenn-i ziraat derslerinin eklenmesi ve coğrafya, hesap, hikmet, kimya ve mevâlid gibi derslerin içeriklerinin zenginleştirilmesi

${ }^{54}$ Salnâme-i Nezâret-i Maârif-i Umûmiye, Birinci Sene, s. 1092-1093. Bu tarihten on y1l sonra, 1.170 kuruş maaşla okulun müdürlüğüne atanan Ahmed Râşid Bey, edebiyat, tarih ve kitabet derslerini okutmuş; üç yıl sonra da Yemen maarif müdürlüğüne atanmıştır (20 Ocak 1908/16 Z 1325, BOA, İrade Maarif, nr. 4/Z 1325)

5528 Haziran 1896 (17 M 1314), BOA, Y.EE., nr. 131/24. İlerleyen yillarda bunlara Ermenice dersi de eklenecekti. Beş yıllık eğitim veren gündüzlü idadîlerde ise, ulum-1 diniye, Arapç, Farsça, Türkçe, Fransızca, hesap, hendese, coğrafya, tarih, usul-i defter, malumat-1 fenniye, hüsnühat ve resim dersleri okutulmaktaydı (B. Kodaman, Abdülhamid Devri Ĕ̆itim Sistemi, s. 132). 
kararlaştırıldı. ${ }^{56}$ Nitekim Sivas idadîsinin 1898 yılından sonraki programında değişiklikleri görmek mümkündür. Bu dönemde padişahın iradesiyle, diğer idadîlerde olduğu gibi Sivas idadîsinde de bir ziraat şubesi kuruldu. Modern materyal ve malzemelerle demirbaş listesi zenginleştirilen okulda, 1903 yılında 300 gündüzlü öğrenci okumaktaydı. Okulda bir de müze bölümü teşkil edilmişti. Müzede birçok önemli eski eser ve sikkeden başka, vilayet dâhilinde yetişen ağaç ve bitki örnekleriyle, çeşitli maden numuneleri bulunuyordu. ${ }^{57^{3}}$

İdadî binası, inşa edilişinin onuncu yılında bir tamir geçirmiştir. Bununla ilgili olarak Osmanlı Arşivi'nde bulunan birkaç belge, tamir için satın alınacak bin tuğlanın ebatları ve fiyatı ile, toplam inşaat masrafı hakkında ilgili makamlar arasında cereyan eden yazışmadan başka bilgi içermemektedir. ${ }^{58}$ Yücel'in bu onarım sırasında yapının saçaklarının düzeltildiğini belirtmesi ${ }^{59}$ söz konusu tuğlaların çatı inşaatında kullanılmış olabileceğini düşündürmektedir.

II. Abdülhamid devri sonlarında, yurt çapındaki idadî sayısı 109'a ulaşmıştı. Bunların 9'u İstanbul'da, 100'ü taşradaydı; okullardaki toplam öğrenci sayısı 20.000'e yaklaşmıştı. II. Abdülhamid döneminde vilayetlerde sultânî açmanın güçlüğü göz önüne alınarak idadîler yedi yıla çıkarılmış, gerçekten de vilayet idadîleri sultânîlerden beklenen hizmeti vermişlerdir. II. Meşrutiyetin ilanından sonra (1908) ise, ortaöğretim konusunda yapılması düşünülen islahata paralel olarak bazı vilayet merkezlerindeki idadîler sultânîye çevrildi. ${ }^{60}$ Bu kapsamda Sivas idadîsi de Sivas sultânîsi oldu. Bu dönüşümün tarihi tespit edilememiş olmakla birlikte, Bâbıâli Baskını'ndan sonra kurulan Mahmud Şevket Paşa kabinesinin 1913 yılında Sivas'a vali olarak atadığı Muammer Bey'in, Sivas sultânîsinde tarih öğretmenliği yapmış olması, bu değişikliğin Balkan savaşları yıllarında gerçekleştiğini düşündürmektedir. Vali Muammer Bey Sivas sultânîsinde talebelere vatan

${ }^{56} 3$ Temmuz 1895 (10 Muharrem 1313), BOA, ŞD, nr. 213/50; 12 Ocak 1895 (16 B 1312), BOA, İrade Hususiye, nr. 56/B 1312.

${ }^{37}$ Sivas Vilayeti Salnamesi, nr. 16, Sivas 1321, s. 185. Bu tarihte Tahir Rüşdü Bey okul müdürlüğünü; Abdurrahman, Hakkı ve Sükrü efendiler ise müdür yardımcılıklarını yürütmektedir. Okulda Rifat, Fethullah, Rasih, Hacı Ziya, Necati, Kirkor, Hüseyin ve İbrahim isimli sekiz ögretmen ile bir mubassır görev yapmaktaydı (s. 58). Öte yandan Karahisar-1 Şarkî dışındaki sancaklara da birer idadî açılmış ve vilayetteki idadî sayısı üçe çıkmıştır. 222.700 kuruşa inşa edilen Amasya idadîsi 1895 yılında (Salnâme-i Nezâret-i Maârif- $i$ Umûmiyye, Dördüncü Sene, İstanbul 1319, s. 692); Tokat idadîsi ise 1902 yılında eğitime başlamıştır (Sivas Vilayeti Salnamesi, nr. 16, Sivas 1321, s. 186). 1907 yılında Sivas idadîsinin öğretmen sayısı 10'a, mubassır sayısı ise 2'ye çıkmıştır (Sivas Vilayeti Salnamesi, nr. 17, Sivas 1325, s. 60).

${ }_{38}$ Tamirat için hazırlanan keşif defterinde 165.778 kuruş masraf çıkartılmış olmasına karşın, Maarif Nezareti'nin isteğiyle bu rakam Şehremaneti mühendislerince 140.829 kurusa çekilmiştir (18 Şubat 1902/9 ZA 1319, BOA, ŞD, nr. 217/38). Ardından padişahın da onaylamasıyla tamirata başlanmıştır (15 Nisan 1902/6 M 1320, BOA, İrade Maarif, nr. 1/M 1320 .

${ }^{59}$ H. Â. Yücel, Türkiye'de Orta Öğretim, s. 519.

${ }^{60}$ B. Kodaman, Abdülhamid Devri Eğitim Sistemi, s. 144; C. Öztürk, s. 466. Sivas bağ Amasya idadîsi 1915 yılı sonlarında sultânîye dönüștürülmüștür (20 Ekim 1915/10 ZA 1333, BOA, Dahiliye Nezareti Umûr-1 Mahalliyye ve Vilayât Müdürlüğü (DH.UMVM), nr. 22/13). 
sevgisini ve hizmet aşkını aşılamış, onların Gençlik Mecmuası adıyla bir dergi çıkarmalarını sağlamıştır. Ayrıca vilayet matbaasında Kızılırmak adıyla bir gazete çıkartmıştır. ${ }^{61}$

Osmanlı'nın son döneminde sultânî olarak hizmet veren binanın yüz on beş y1llık geçmişinde yüklenmiş olduğu en önemli misyon, şüphesiz, 4-12 Eylül 1919'da toplanan Sivas Kongresi'ne ev sahipliği yapmış olmasıdır. Kongre sonunda seçilen Heyet-i Temsiliye üyeleri, yine bu binada Anadolu'nun ilk gayrı resmi hükümeti olarak milli mücadele hareketini örgütlemiş, millet iradesinin her türlü baskı ve mandacılığın üstünde olduğunu buradan dünyaya ilan etmişlerdir. Mustafa Kemal Sivas'a geldiğinde eşraftan Şekeroğlu İsmail Efendi'nin konağında ağırlanmış, ${ }^{62}$ karargâh olarak da kendisine mekteb-i sultânî verilmiştir. Kongreye DenizliAydın delegesi olarak katılan Mazhar Müfit Bey, sultânîdeki odaların taksimatı hakkında ayrıntılı bilgi vermiștir. Buna göre binanın batı cephesindeki eski ve asıl girişinin bulunduğu kapıdan girişte solda ve baştaki oda, delegelerin ve binanın emniyetinden sorumlu Ahmet Rasim-zâde Mazlum'a tahsis edilmiş ve bir nevi karakol haline getirilmişti. Yine sol taraf koridorunu takip eden ve merdivenlerin ilerisinde bulunan büyük oda yemek salonu olarak düzenlenmişti. İki taraflı tahta merdivenden yukarıya çıkılınca sağdaki birinci oda Mustafa Kemal Paşa'ya, bunun bitişiğindeki müsamere salonu kongre çalışmalarına tahsis edilmişti. Salonu takip eden oda Rauf Bey'e, merdivenin solunda ve köşedeki büyük dersane de Paşa'nın maiyet memurlarına ayrılmıștı. Birer mektep koğuşu gibi ve fakat muntazam șekilde hazırlanan bu odadaki karyolalarda Hayati, Receb Zühdü, Muzaffer, Mühendis Ruhi ve Nizameddin beyler yatacaklardı. Bu odanın yakınındaki büyük oda İbrahim ve Mazhar Müfit beyler için; merdivenin karşısındaki oda ise Hüsrev (Gerede) ve Refik (Saydam) beyler için hazırlanmıştı. ${ }^{63}$ Kongrenin bitiminden sonra heyet-i temsiliye ile görüşmek amacıyla yurdun çeşitli yerlerinden gelenler de sultânî binasında konaklamışlardı. ${ }^{64}$

Kinross, binanın o tarihteki görünümü ve iç tasarımı hakkında çarpıcı bilgiler vermektedir: Sivas Kongresi, etrafında 13. yüzyıl Selçuklu

${ }^{61}$ Mehmet Aldan, İz Bırakan Mülkî Idare Amirleri, T.C. İçişleri Bakanlığı Yayını, Ankara 1995, I, 274. Kendisi de sultânî hacalığı yapmış olan Mahir İz hatıralarında, bu okullar hakkında şunları yazar: "Sultânî mektebi bir vilayetin beyni mesâbesindedir. Her branştan en yüksek tahsil gören münevver zümre oradadır. Bir vilayette onun fevkinde bir mütefekkir topluluğu yoktur." (Mahir İz, Yılların İzi, Kitabevi Yayınları, 3. Baskı, İstanbul 2003, s. 83).

${ }^{62}$ Şekeroğlu İsmail Efendi Müdafaa-i Hukûk-1 Milliye üyesi idi. Kongreye katılan 28 delege otuz iki gün boyunca bunun evinde kalmıştır (Sadettin Gümüş, Sivas Kongresi, Sebat Matbaası, Sivas 1974, s. 39-40).

${ }^{63}$ Mazhar Müfit Kansu, Erzurum'dan Ölümüne Kadar Atatürk'le Beraber, TTK, 4 Baskı, Ankara 1997, I, 206.

${ }_{64}$ Vali Reșid Paşa 22 Ekim tarihli yazısında Ankara valisi Muhyiddin Paşa, Corum mutasarıffı Sâmih Bey ve Niğde mutasarrıfı Cavid Bey ile bunların refakatinde Sivas'a gelen kişilerin birkaç gün şehirde kaldıktan sonra İstanbul'a hareket ettiklerini, Sivas'ta bulundukları süre içerisinde bir kısmının mekteb-i sultânî binasında kaldıklarını belirtmistir (22 Ekim 1919/25 M 1338, BOA, Dâhiliye Nezareti Kalem-i Mahsus Müdüriyeti (DH. KMS), nr. 53-3/3). 
Türklerinden kalma zarif yapıların bulunduğu, duvarları beyaz badanalı klasik bir lise binasında toplanmıştı. Bahçeye, yeni kolordu komutanı Selahaddin Bey'in askerlerinin kullandığı bir tek koruyucu sahra topu yerleştirilmişti. Toplantılar, taşra zevkine göre süslenmiş, uzun, dikdörtgen biçimindeki bir sınıfta yapılıyordu. Döşemeler ve duvarlar, Sivaslıların getirdikleri halılarla süslenmişti. Odanın bir köșesine namaz seccadesi serilmişti. Delegeler, üstüne mürekkep hokkası koymak için delikler olan yarım düzine kadar kaba okul sıralarına oturmuşlardı. Mustafa Kemal'e ayrı bir masa verilmiş, arkasındaki duvara da üzerinde "Padişahım çok yaşa" yazılı bir halı asılmıştı. Ancak o, bu halıyı, havı dökülmüş koltuğuna örterek üzerine oturmayı daha uygun buldu. Salonun bitişiğinde Mustafa Kemal için hazırlanmış olan yatak odasında geniş bir karyola, yaldız taklidi pirinçten lambalar ve özel toplantılar için tedarik edilmiş birkaç sandalye bulunuyordu. Yatağın üstünde, fiyonklarla, çiçek motifleriyle ince ince işlenmiş ipek bir örtü seriliydi. Bu örtüyü, Sivaslı bir genç kız, çeyiz sandığından çıkararak, Mustafa Kemal Paşa'ya armağan etmişti.".6.

Kongrenin yapıldığı tarihlerde Sivas sultânîsinde mantık, felsefe, edebiyat muallimi olarak görev yapan Sadeddin Bey tarafından yazılan ve salona asılan "Kongre merkezi olmuş idi bu Sultânî / Vatan ve milleti tahlis, hem de sultâni" beyti, binanın misyonunu en güzel ifade eden sözlerdir. ${ }^{66}$ Kongre günlerinde Sivas'a gelen ve Atatürk'le manda meselesini tartışan Amerikalı General Harbord'un Sivas sultânîsi hakkında "Konforu eksik ve dış görünüşleriyle devirlerini tamamlamış bu ve benzer yapılarda, derinliğini görerek anladığım büyük bir milletin kaderine ümitli istikametler vermenin mücadelesi yapılıyordu" şeklindeki mütalaası da oldukça anlamlıdır. ${ }^{67}$

Kongre çalışmaları sırasında Sivas sultânîsine kayıtlı öğrenci sayısı 140 'tı. Ancak bunların sadece yarısı öğrenimini sürdürmekteydi. Kongre çalışmaları sırasında eğitimin aksamaması için okul bir başka binaya nakledilmişti. Toplantıların bitmesi ve Heyet-i Temsiliye'nin Ankara'ya gitmesinden sonra sultânî binasına ani bir kararla astsubay okulu öğrencileri yerleştirilmişti. ${ }^{68}$

O sırada Sivas'ta muhacir ve şehit çocuklarıyla yaşlı kimsesizlerden oluşan barınmaya muhtaç yaklaşık bin kişi bulunuyordu. Bunlar şehir dışında bir Ermeni manastırına doldurulmuştu. Vali Reşid Paşa onları sefaletten kurtarmak için şehir içerisinde bir bina aramış, fakat bulamamıştı. Bir süre sonra tehcirden dönen Ermeniler, manastırlarını isteyince

${ }^{65}$ Lord Kinross, Atatürk Bir Milletin Yeniden Doğuşu, çev. N. Sander, İstanbul 2001, s. 226-227.

${ }^{66}$ S. Gümüş, Sivas Kongresi, s. 41. Bazı yazarlar, bu beytin, Erzurum Kongresi'ne Sivas'ı temsilen katılmış olan Fazlullah (Moral) Hoca tarafından yazdırıldı̆̆ını kaydetmektedir (H. Çağdaş, Sivas İdâdîsi, s. 31). s. 94 .

${ }^{67}$ Cemal Kutay, Türk Milli Mücadelesinde Amerika, Boğaziçi Yayınları, İstanbul 1979,

68 30 Ekim 1919 (5 S 1338), BOA, Dâhiliye Nezareti İdâre-i Umûmiye Müdüriyeti (DH.IUM), nr. 7-4/1-30. 
kimsesizlerin barınma problemi ortaya çıktı. Şehirde uygun bina bulunamayınca, bir kısmı yine şehir dışında askeriyeye ait bazı boş binalara yerleștirildi. Fakat kış gelince askeriye binaların tahliyesini istemiş, kimsesizler yine açıkta kalmıştı. Bunun üzerine kolordu kumandanının yardımıyla erkek çocuklar askerî rüşdiyelere kaydedildi. Bir kısım çocuklar akrabalarının yanına verilirken, bir kısmı da evlatlık olarak çeşitli ailelere dağıtıldı. Bununla birlikte, barınak problemi çözülemeyenlerin sayısı 500'ün üzerindeydi. Reşid Paşa, Maarif Nezareti'yle yazıştıktan sonra bunlar için bir kız dârüleytamı ile sanayi okulu açılması kararlaştırıldı. Ancak bu iş için bina inşa etmek parasal açıdan mümkün olmadığından, sultânî binasını kullanmak istedi. Zira bu bina 700 kişiyi barındırabilecek büyüklükte olmasına karşın, sadece 70 öğrenci devam etmekteydi. Reşid Paşa hem barınmaları hem de okuma-yazma ve sanat öğrenerek topluma kazandırılması düşüncesiyle kimsesizleri sultânî binasına yerleştirdi. İstanbul'dan müdire ve muallimler getirtti, dokuma tezgâhları ve başka makineler tedarik etti. Amerika Şark-1 Karîb Muâvenet Heyeti'nden ${ }^{69}$ yatak, yorgan ve çamaşır sağladı. Ancak bu durum bazı sultânî öğrencileri velilerinin şikayetlerine neden oldu. Veliler hükümete, çocuklarının dar binada eğitim gördüklerinden dolayı okuldan soğuduklarını, hatta okulu terk ettiklerini içeren telgraflar gönderdiler. Bunun üzerine Maarif Nazırı, sultânînin boşaltılmasını ve okulun gerçek öğrencilerine verilmesini istedi. Vali Reşid Paşa Dâhiliye Nezareti'ne gönderdiği uzun yazısında yaptığı işin gerekçelerini sıraladı. İstanbul'da yetimlerin sokak ortasında kalmalarına rıza göstermeyen padişahın " $B u$ yetimlerin temin- $i$ istirahati benim boynuma borçtur” diyerek Valide Sarayı ile Kağıthane Kasrı'nı kimsesizlere tahsis ettiğini hatırlatan Reşid Paşa, "...padişahımızın şu suretle saraylarda oturmaya lâyık gördüğ̈̈ yetimleri Sivas'taki mekteb-i sultânî binasına yerleştirerek hayatlarını kurtarmaya çalışmakla fena bir iş görmediğimi zannediyorum" ifadesini kullanmıştır. Reşid Paşa, çocukların okumayı terk ettikleri yolundaki veli şikâyetleri hususunda ise, " $\mathrm{Bu}$ hadise muallim efendilerin daha büyük, daha muhteşem bir binada ikamet heves-i tıflânesine müteallimlerin de iştirâkiyle oynanmak istenen bir komediden ibâretti. Fakat uzun sürmedi, bir hafta sonra hakikat ve yapılan işteki isâbet anlaşılarak talebe de kemâ fi's-sâbık mekteplerine devama başladılar" cevabını vermiştir. Reşid Paşa, sultânî öğrencilerinin geçici konağa rahatlıkla sığdıklarını, fakat aynı binanın 500 kimsesizi barındıramayacağını belirtmiş, bu şekildeki düzenlemeden başka çare bulunmadığını, fakat yine de padişah

${ }^{A}$ Protestan misyonerler tarafından kurulan Amerikan Yakındoğu Yardım Komitesi,1915 yılında tehcire tabi tutulan Ermenilere yiyecek, giyecek ve sağlık hizmetleri gibi insani konularda yardım etmek amacıyla kurulmuş bir örgüttür. Komitenin yardımlarından Müslümanlar sadece yüzde iki oranında yararlanmıştır. Mayıs 1919 yılında Dodd, Barton, Lynn, Sutherland, Fornsworth, Barlett ve Miss. Graffam'dan oluşan bir heyet Sivas'a gelmis buradaki hastaneyi tamir ettikten sonra Ermeni kadın ve cocuklarının sorunlarına eğilmişlerdi (Fatih Gencer, Ermeni Soykırım Tezinin Oluşum Sürecinde Amerikan Yakın Doğu Yardım Komitesi, Alternatif Yayınları, İstanbul 2006, s. 94). 
iradesi okulun boşaltılması yönünde tecelli ederse, bu takdirde 500 yetim ve kimsesizin durumu hakkında bir çare tavsiye edilmesini istemiştir. ${ }^{70}$

Binanın ne kadar süre ile yetimhane olarak kullanıldığını tespit etmek mümkün olmasa da, yukarıda bahsi geçen astsubay okulunun Tokat'a taşınmasından sonra yeniden Sultânî'ye dönüștürüldüğü bilinmektedir. ${ }^{71}$ Tam bu sırada Cumhuriyet'in ilanıyla birlikte sultânîlere "lise" adı verilmesi kararı üzerine Sivas sultânîsi de 1924 yılından itibaren Sivas Lisesi adını almıştır. Bu tarihte binanın yeni ve önemli bir işlev daha yüklendiğini görüyoruz. Hars Müdürlüğü'nün emriyle vilayetin çeșitli yerlerinde dağınık halde bulunan tarihi eserler bir araya getirilerek lise binasında teşhire sunulmuştur. 1923 yılında kabaca tasnif edilerek ziyarete açılan bu müze nüvesi, Sivas müzeciliğinde ilk somut adım olarak kabul edilmektedir. Ancak müzenin lise binasında gelişemeyeceğini hesaba katan yetkililer, 1927 yılında koleksiyonları Gök Medrese'ye naklettiler. ${ }^{72}$ Bu tarihlerde lise binasında bir başka müze vücuda getirilmesi düşünüldü. Sivaslı bir grup genç, kongre sırasında Mustafa Kemal'in kaldığı odada kullandığı eşyayı ve kongreyle ilgili vesikaları bir araya getirip, odayı da o zamanki haline dönüştürerek müze haline getirdiler. ${ }^{73}$ Böylece Atatürk'ün eşyası ve kongreyle ilgili belgeler uzun yıllar korunabilme imkanına kavuştu.

Cumhuriyet idaresi sırasında binanın dıș cephesinde bazı değişimler meydana gelmiştir. 1926 yılında çıkarılan 819 sayılı kanunla, Maarif Vekâleti 1934 yılına kadar birçok okul ya yaptırmış ya da tamir ettirmiştir. Her vilayetin kendi bütçesinden $\% 10$ nispetinde ayırdığı ödenekle gerçekleştirilen bu faaliyetler kapsamında Sivas Lisesi önüne bir pavyon inşa edildi. Bina esaslı bir onarımdan geçirildi. ${ }^{74} 1930$ yılında, binanın arka bahçesine paralel olarak İstasyon Caddesi'nin açılması üzerine, okulun giriş kapısı bu yöne, yani doğu tarafına nakledildi. Bu değişiklik sırasında mutfak, kiler ve hamam gibi sonradan eklenen bölümler ile öteden beri yer alan kale duvarı yıktırıldı. Düz dam şeklindeki çatısı sacla kaplandı. Binanın batı yönündeki mescit ${ }^{75}$ ile bir ev istimlâk edilerek, yeni bir bina yaptırıldı. 1933 Mayıs'ından itibaren okulun yatılı öğrenci sayısının artması üzerine, modern ve güzel bir pansiyon binası inşa edildi. ${ }^{76}$

${ }^{70} 19$ Şubat 1920 (28 CA 1338), BOA, DH.IUM, nr. 7-4/1-70.

${ }^{71}$ H. Denizli, Sivas Tarihi ve Anitlar, , s. 166.

${ }^{72}$ Hikmet Gürçay, "Sivas Müzesi”, Önasya, Y1l: 7, c. 7, S. 73, 1970-1971, s. 62.

73 "Bu sene kongrenin yıldönümünde bu çok kıymetli müzenin resm-i küŝadının yapılacă̆ını memnuniyetle haber aldık" (İsmail Hakkı-Rıdvan Nâfiz, Sivas Sehri, İstanbul 1346-1928, s. 13).

${ }_{75}^{74}$ H. Â. Yücel, Türkiye'de Orta Öğretim, s. 249

${ }^{75}$ Bu mescit, Sivas valisi Vezir Elhac Osman Paşa (1815-1816) zamanında yaptırılmıs olmakla birlikte, vali Ahmed İzzet Paşa tarafından genişletilip bir bakıma yeniden inşa edildiği için İzzet Paşa Camii adıyla anılmaktaydı (Sivas Vilayet Salnâmesi, nr. 10, Sivas 1300 , s. 33, 38). Kongre binasının yanındaki bu cami, Sivas Sehri yazarlarına göre, 1927 yılında hükümet meydanını genişletme faaliyetleri sırasında ortadan kaldırılmıştır. Yerinde bugünkü Atatürk anıtının bulunduğu bu camiin mimarî bir özelliği bulunmuyordu (ì. HakkıR. Nâfiz, Sivas Sehri, s. 13)

${ }^{76}$ H. Â. Yücel, Türkiye'de Orta Öğretim, a.y. Bu tarihte okulun teneffüs odası ile yemekhanesi dışında 24 odası, ayrıca kongrenin yapıldığı büyük ve tarihi konferans salonu 
Cumhuriyet'in ilanından sonra yeniden ele alınan eğitim öğretim politikasının bir gerçeği olarak Sivas Lisesi, Anadolu liseleri içerisinde "sembol mektep" kimliğine kavuşturulmuştur. Kendisi de Sivas Lisesi mezunu olan şair Cahit Külebi, 1930'larda, Ahmet Kutsi Tecer'in Sorbon mezunu olarak lisenin edebiyat öğretmenliğine tayin edilmesini bu nedene bağlar. ${ }^{77}$

Mustafa Kemal Atatürk sonraki Sivas ziyaretleri sırasında binayı gezerek hatıralarını yinelemiş; 13 Kasım 1937 tarihindeki ziyaretinde, geometri dersinin işlendiği bir sınıfa girmiş ve burada Arapça kökenli bazı terimlerin yerine, "açı", "kenar", "üçgen” gibi karşılıklarını kullanmıştır.

Kongre binası 1983 yılına kadar lise olarak kullanılmaya devam etti. Ancak 1960'ların sonlarında vilayet merkezinde yeni bir lise kurulması gündeme gelince Sivas Lisesi için Taşlısokak'ta yeni bir bina inşa edilmiş, kongre binasının adı ise 4 Eylül ve Kongre Lisesi olarak değiştirilmiştir. 1981 yılında Sivas'ı ziyaret eden Devlet Başkanı Kenan Evren, binanın tarihi ve mimari önemine vurgu yaparak, buranın daha iyi korunması ve anlamlı bir işleve kavuşturulması amacıyla girişim başlattı. İki yıl sonra Kongre Lisesi başka bir binaya nakledilerek, kongre binası Atatürk ve İnkılap Müzesi'ne dönüştürüldü. Daha sonra uzun bir tamir süreci geçiren bina, 1990 yılındaki bir kararla ve törenle "Sivas Atatürk Kongre ve Etnoğrafya Müzesi" haline getirilerek bugünkü kimliğine kavuşturuldu ${ }^{78}$.

Sonuç olarak Sivas Kongresi binası, XIX. yüzyılın ikinci yarısında belli bir üslup gözetilmeden, ancak Avrupa taklidi olsa da belli bir proje dâhilinde inşa edilen Osmanlı resmî binalarının tipik bir örneğidir. II. Abdülhamid döneminde gerek merkezde, gerekse taşrada inşa edilen yapılarda büyüklük ve şatafatın ön planda tutulması, Avrupalı devletlerin ve imparatorluktan kopmak emelindeki ulusların yıkıcı faaliyetlerine karşı, güçlü bir Devlet-i Aliyye görünümü vermek düşüncesiyle açıklanabilir. Sivas örneğinde olduğu gibi, idadî binalarının inşası sırasında gözetilen hususlar da bu düşüncenin ürünüdür. Osmanlı'nın son döneminde çağdaş eğitim sitemi ve teknolojisini hayata geçirmek isteyen felsefenin bir parçası olarak inşa edilen Sivas idadîsi, sonraki dönemlerde sultani ve lise olarak eğitim hizmeti vermiş, bir süre yetimhane olarak kullanılmış, nihayet Sivas müzeciliğinin nüvesini oluşturmuştur. Yaklaşık bir asır okul olarak kullanılan bu binadan yetişen binlerce vatansever öğrenci gerek Osmanlı döneminde gerekse Cumhuriyet Türkiyesinde bürokraside, öğretim kurumlarında, orduda ve parlamentoda görev almışlardır. Halen müze olarak kullanılan bina, Gazi Mustafa Kemal'in belirttiği gibi, istiklal mücadelesinin programının çizildiği bir karargâh olması bakımından kutsal bir mekandır.

bulunuyordu (Hasan Tahsin, Sivas Vilayeti Sthhî ve İctimaî Coğrafyası, Sıhhat ve İctimâ̂ Muavenet Vekâleti Yayını, İstanbul 1932, s. 126).

n" "110. Yılında Lisemiz", Sivas Lisesi 110. Yıl Ozel Sayısl, S. 10, Nisan 1998, s. 14.

${ }^{78}$ H. Çağdaş, Sivas İdâdîsi, s. 33; H. Denizli, Sivas Tarihi ve Anıtları, s. 166. 


\section{KAYNAKÇA}

\section{Osmanlı Arşivi Belgeleri*}

Bâbıâli Evrak Odası, Sadaret Mektubî Mühimme Kısmı

Dâhiliye Nezareti İdâre-i Umûmiye Müdüriyeti

Dâhiliye Nezareti Kalem-i Mahsus Müdüriyeti

Dahiliye Nezareti Umûr-1 Mahalliyye ve Vilayât Müdürlüğü

İrade Tasnifi; Dahiliye, Hususiye, Maarif, Meclis-i Mahsus iradeleri

Meclis-i Vükelâ Mazbataları

Şûrâ-yı Devlet Tasnifi

Yildız Esas Evrakı

Yıldız Perakende Evrakı Umum Vilayetler Maruzatı

Yıldız Perakende Evrakı Arzuhaller ve Jurnaller

\section{Araştırma Eserler ve İncelemeler}

Aldan, Mehmet, İz Bırakan Mülkî İdare Amirleri, c. I, T.C. İçişleri Bakanlığı Yayını, Ankara 1995.

Aslantaş, Selim, "Bir Osmanlı Bürokratı: Mehmed Memduh Paşa”, KÖK Sosyal ve Stratejik Araştırmalar Dergisi, c. III, S. 1 (Bahar 2001), Ankara 2001, s. 185202.

Çağdaş, Haluk, "Sivas İdâdîsi”, Tarih ve Toplum, S. 90, Haziran 1991, s. 30-33.

Denizli, Hikmet Denizli, Sivas Tarihi ve Anıtları, Özbelsan A. Ş. Yayını, Sivas Ts.

Ergin, Osman, Türk Maarif Tarihi, c. II, Eser Matbaası, İstanbul 1977.

Fortna, Benjamin J., Mekteb-i Hümayûn Osmanlt İmparatorluğu'nun Son Döneminde İslam, Devlet ve Eğitim, çev. P. Siral, İstanbul 2005.

Gencer, Fatih, Ermeni Soykırım Tezinin Oluşum Sürecinde Amerikan Yakın Doğu Yardım Komitesi, Alternatif Yayınları, İstanbul 2006.

Gümüş, Sadettin, Sivas Kongresi, Sebat Matbaası, Sivas 1974.

Hasan Tahsin, Sivas Vilayeti Sıhhî ve Íctimầ Coğrafyası, Sihhat ve İctimaî Muavenet Vekâleti Yayını, İstanbul 1932.

İsmail Hakkı-Rıdvan Nâfiz, Sivas Şehri, İstanbul 1346-1928.

İz, Mahir, Yılların İzi, Kitabevi Yayınları, 3. Baskı, İstanbul 2003.

Gürçay, Hikmet, “Sivas Müzesi”, Önasya, Yıl: 7, c. 7, S. 73, 1970-1971, s. 62.

• Belge numaraları metin içinde gösterilmiştir. 
Kansu, Mazhar Müfit, Erzurum'dan Ölümüne Kadar Atatürk'le Beraber, c. I, TTK, 4. Bask1, Ankara 1997.

Kinross, Lord, Atatürk Bir Milletin Yeniden Doğuşu, çev. N. Sander, İstanbul 2001.

Kodaman, Bayram, Abdülhamid Devri Ĕ̆itim Sistemi, Ankara 1991.

Kutay, Cemal, Türk Milli Mücadelesinde Amerika, Boğaziçi Yayınları, İstanbul 1979.

Maarif-i Umûmiye Nezaret-i Celilesi İdâresinde Bulunan Mekâtib-i İbtidâiyye, Rüşdiye, $\dot{I}$ 'dâdiye, Âliye ile Mekâtib-i Husûsiye ve Ecnebiyyenin ve Dersaâdet'te Tahriri İcrâ Kılınan ve Taşrada Mevcûd Bulunan Kütübhânelerin Itatistiki, 1310-1311 Sene-i Dersiyye-i Mâliyesine Mahsûsdur, Osmaniye Matbaası, Dersaadet.

Maarif-i Umûmiye Nezaret-i Celilesi İdâresinde Bulunan Mekâtib-i Íbtidâiyye, Rüsdiye, I'dâdiye, Âliye ile Mekâtib-i Husûsiye ve Ecnebiyyenin ve Dersaâdet'te Tahriri İcrâ Kılınan ve Taşrada Mevcûd Bulunan Kütübhânelerin Itatistiki, 1311-1312 Sene-i Dersiyye-i Mâliyesine Mahsûsdur, Matbaa-yı Amire, İstanbul 1318.

Mahmud Cevad, Maarif-i Umûmiye Nezâreti Tarihçe-i Teşkilat ve İcraatı, c. I, İstanbul 1338 .

Özgüven, Burcu, "İdadî Binaları", Tarih ve Toplum, S. 82, Ekim 1990, s. 44-46.

Öztürk, Cemil, "İdâdî", DIA, İstanbul 2000, XXI, s. 465.

Said Paşa, Said Paşa'nın Hâtırâtı, c. I, Dersaadet 1328.

“Söyleşi: Osmanlı'dan Bugüne Hükümet Konakları”, Yöneten: G. Birkan, Katılanlar: İ. Ortaylı ve dğr., Mimarlık, S. 84/5, Mayıs 1984.

Yücel, Hasan-Âli Yücel, Türkiye'de Orta Öğretim, Ankara 1994.

“110. Yılında Lisemiz”, Sivas Lisesi 110. Yıl Özel Sayısı, S. 10, Nisan 1998.

\section{Süreli Yayınlar}

Sivas Vilayet Gazetesi,1297 yıll.

Sivas Vilayet Salnâmesi, nr. 10, Sivas 1300.

Salnâme-i Vilayet-i Sivas, nr. 15, Sivas 1308.

Sivas Vilayeti Salnamesi, nr. 16, Sivas 1321.

Sivas Vilayeti Salnamesi, nr. 17, Sivas 1325.

Salnâme-i Nezâret-i Maârif-i Umûmiye, Birinci Sene, İstanbul 1316.

Salnâme-i Nezâret-i Maârif-i Umûmiyye, İkinci Sene, İstanbul 1317.

Salnâme-i Nezâret-i Maârif-i Umûmiyye, Üçüncü Sene, İstanbul 1318.

Salnâme-i Nezâret-i Maârif-i Umûmiyye, Dördüncü Sene, İstanbul 1319.

Salnâme-i Nezâret-i Maârif-i Umûmiyye, Altıncı Sene, İstanbul 1321. 


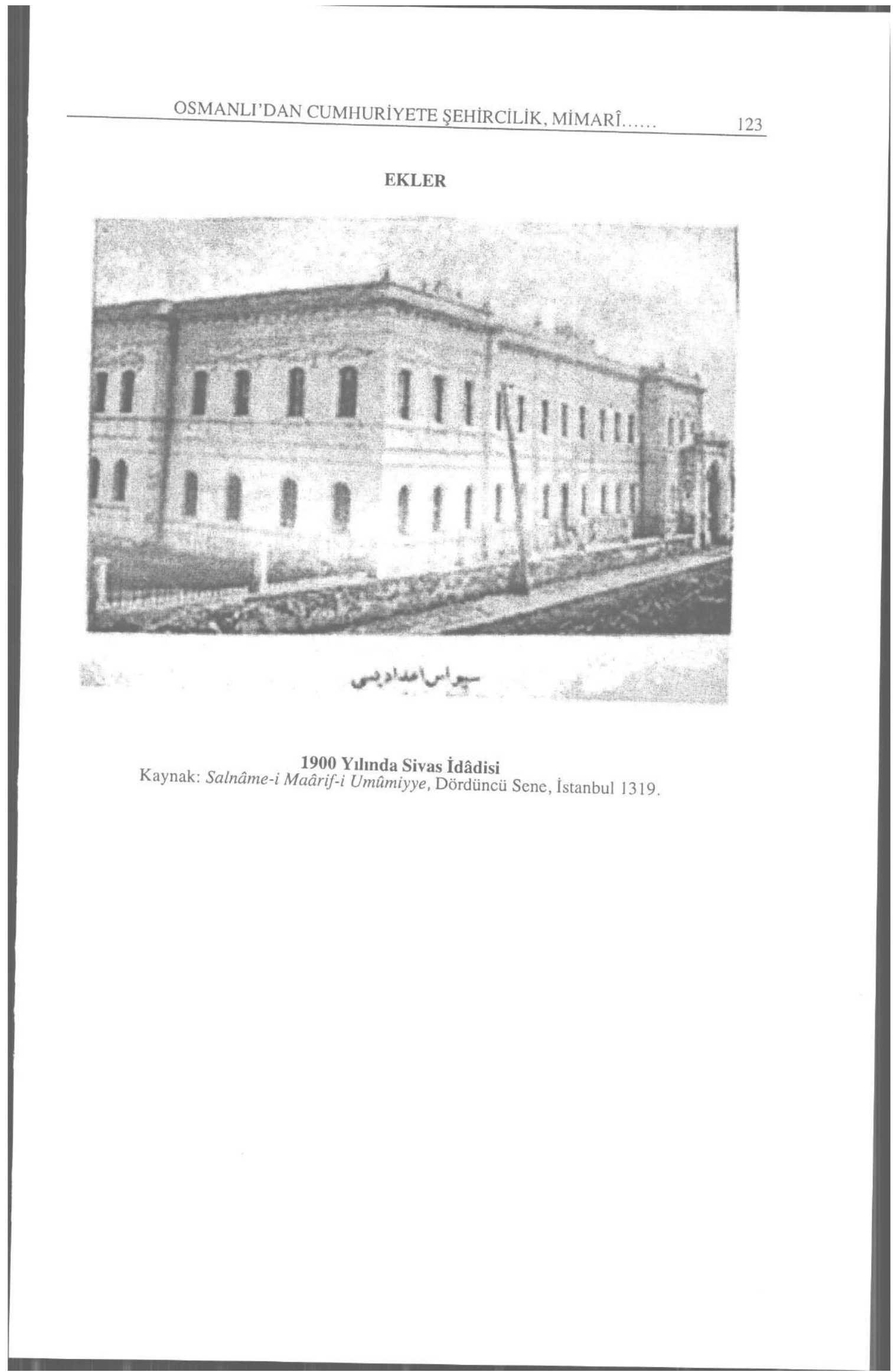




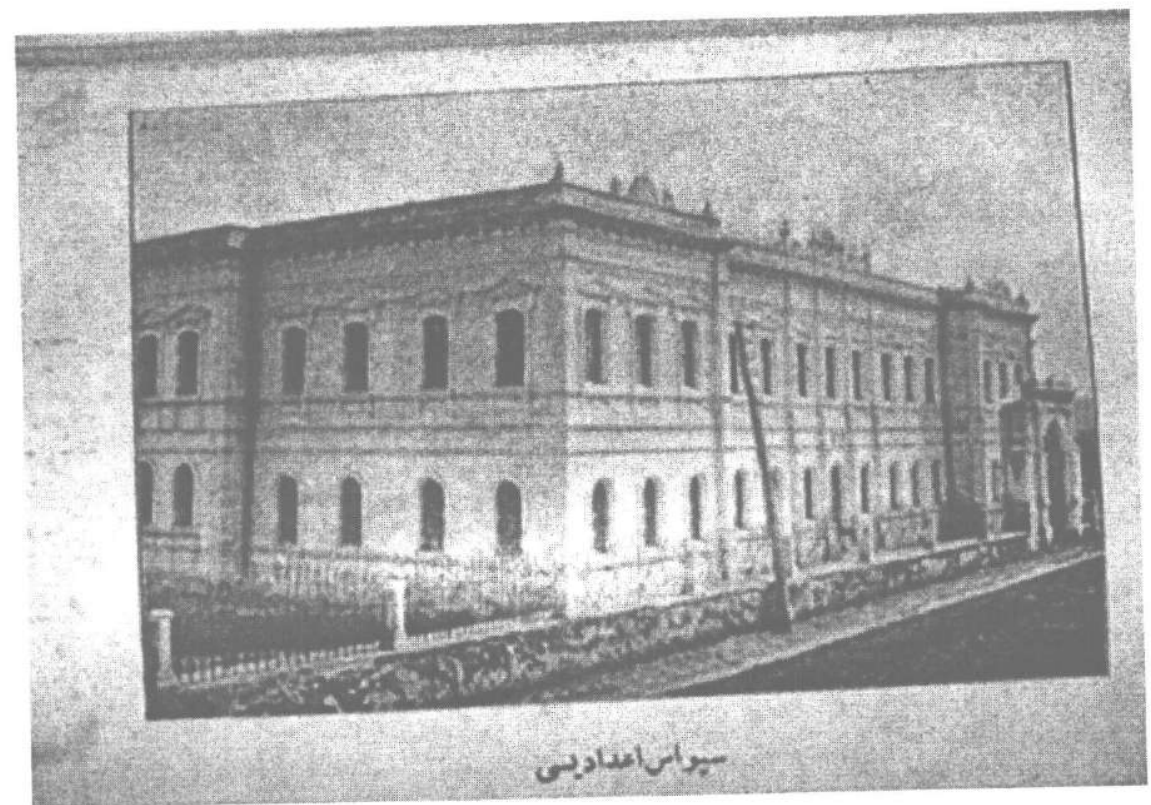

Kongre Günlerinde Sivas Sultânîsi

Kaynak: Servet-i Fünûn, Dördüncü Sene, Eylül 1919. 


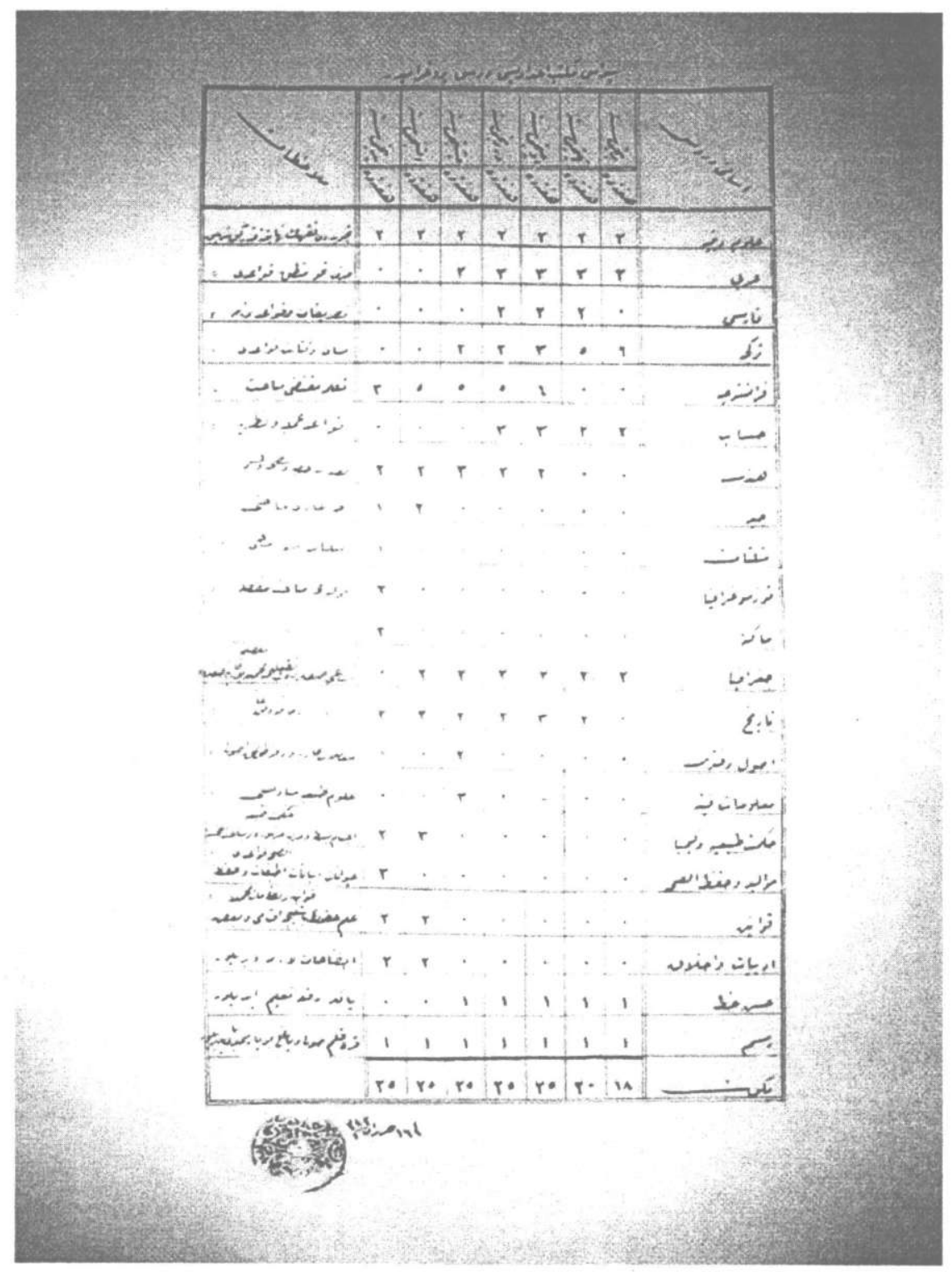

Sivas İdadîsi Haftalık Ders Programı, 1896

(Kaynak: BOA, Y.EE., nr. 131/24) 